<短 報 $>$

\title{
北九州に土着した $\mathrm{E}$ 型肝炎ウイルス株による急性肝炎の 2 例
}

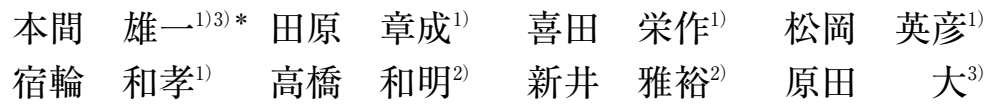

緒言 : 2001 年に日本固有の $\mathrm{E}$ 型肝炎ウイルス (HEV) 株が報告されて以降1), $\mathrm{E}$ 型肝炎の国内感染例が日本各 地で報告されるようになり，遺伝子解析から各地に土 着する $\mathrm{HEV}$ の実態が明らかになりつつある. しかし， 九州地方における $\mathrm{E}$ 型肝炎の報告は少なく，その実態 については不明な点が多い. 今回, 同時期に発症し, 遺伝子解析により北九州に土着した genotype 3 の $\mathrm{HEV}$ 株によると考えられた $\mathrm{E}$ 型急性肝炎の 2 例を経験した ので報告する.

症例 1：70 歳代の男性. 主訴：食欲不振, 下痢, 嘔 吐. 既往歴：特記事項なし. 生活歴：海外渡航歴や動 物の生肉, 内臓等の摂取歴や飼育歴なし. 現病歴 : 2012 年 8 月に食欲不振, 下痢, 嘔吐が出現し近医を受診し, AST 963 IU/L，ALT 896 IU/L と肝障害を認めた．第 4 病日に当科紹介され同日入院. 入院時現症：身長 150 $\mathrm{cm}$, 体重 $47.8 \mathrm{~kg}$, 体温 $36.6^{\circ} \mathrm{C}$. 眼球結膜に黄染あり. 腹部に特記所見なし. 入院時検査所見 : T-Bil $3.2 \mathrm{mg} / \mathrm{dL}$, AST 750 IU/L, ALT 911 IU/L, $\gamma$-GTP 231 IU/L. IgA$\mathrm{HEV}$ 抗体, IgM-HEV 抗体, IgG-HEV 抗体が陽性で, 血清 HEV RNA 2.6 log copy/mL と陽性, 便中 HEV RNA は除性. HEV の genotype は 3 .

症例 2 : 70 歳代の男性. 主訴 : 全身倦㐭感. 既往歴 : 2 型糖尿病. 生活歴 : 海外渡航歴や動物の生肉, 内臓等 の摂取歴や飼育歴なし. 現病歴：リウマチ性多発筋痛 症にてプレドニゾロン，メトトレキサートを内服中． 2012 年 8 月に AST $94 \mathrm{IU} / \mathrm{L}, \mathrm{ALT} 101 \mathrm{IU} / \mathrm{L}$ とはじめ て肝障害を指摘された。薬物性肝障害を疑われ被疑薬 を中止されたが，第 15 病日に AST $414 \mathrm{IU} / \mathrm{L} ， \mathrm{ALT}$ $407 \mathrm{IU} / \mathrm{L}$ と増悪を認めた. 第 16 病日に当科紹介され同

1) 産業医科大学若松病院消化器内科

2) 東芝病院研究部

3）産業医科大学第 3 内科学

*Corresponding author: y-homma@med.uoeh-u.ac.jp <受付日2013年1月3日 $><$ 採択日2013年4月24日 >
日入院. 入院時現症：身長 $160 \mathrm{~cm}$, 体重 $46.6 \mathrm{~kg}$, 体温 $36.4^{\circ} \mathrm{C}$. 腹部は平坦, 軟で右季肋部に圧痛あり。肝脾は 触知せず。入院時検査所見：AST 508 IU/L, ALT 581 IU/L, $\gamma$-GTP 134 IU/L. IgM-HEV 抗体は院性, IgAHEV 抗体, IgG-HEV 抗体が陽性で, 血清 HEV RNA $3.8 \log \mathrm{copy} / \mathrm{mL}$ と陽性, 便中 HEV RNA も陽性. HEV の genotype は 3 .

入院後経過 (Fig. 1a, b) : 2 例とも, IgA-HEV 抗体 陽性，血清 HEV RNA 陽性であり，E型急性肝炎と診 断した. 保存的に加療を開始したが，重症化や劇症化 の兆候はなく, 肝障害は徐々に改善し, アルブミンの 上昇，ビリルビンの低下を認めた。 その後は肝炎の再 燃は認めなかった。

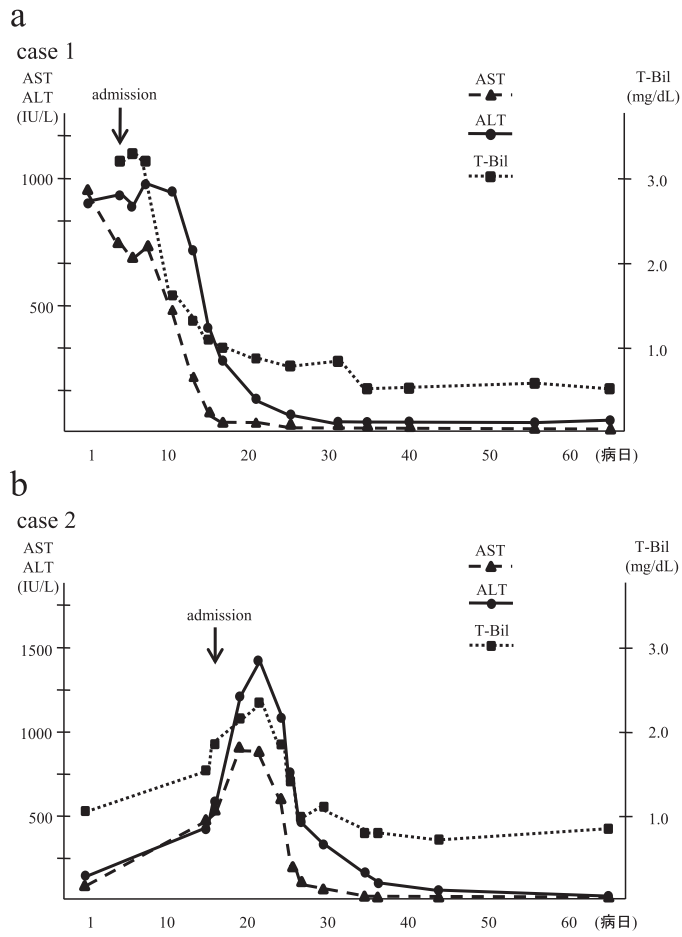

Fig. 1 Clinical course of the two patients. 
[GENETYX-MAC: Evolutionary Tree] Method: NJ Bootstrap Trial: 1000

\section{HEV ORF1 326nt}

5

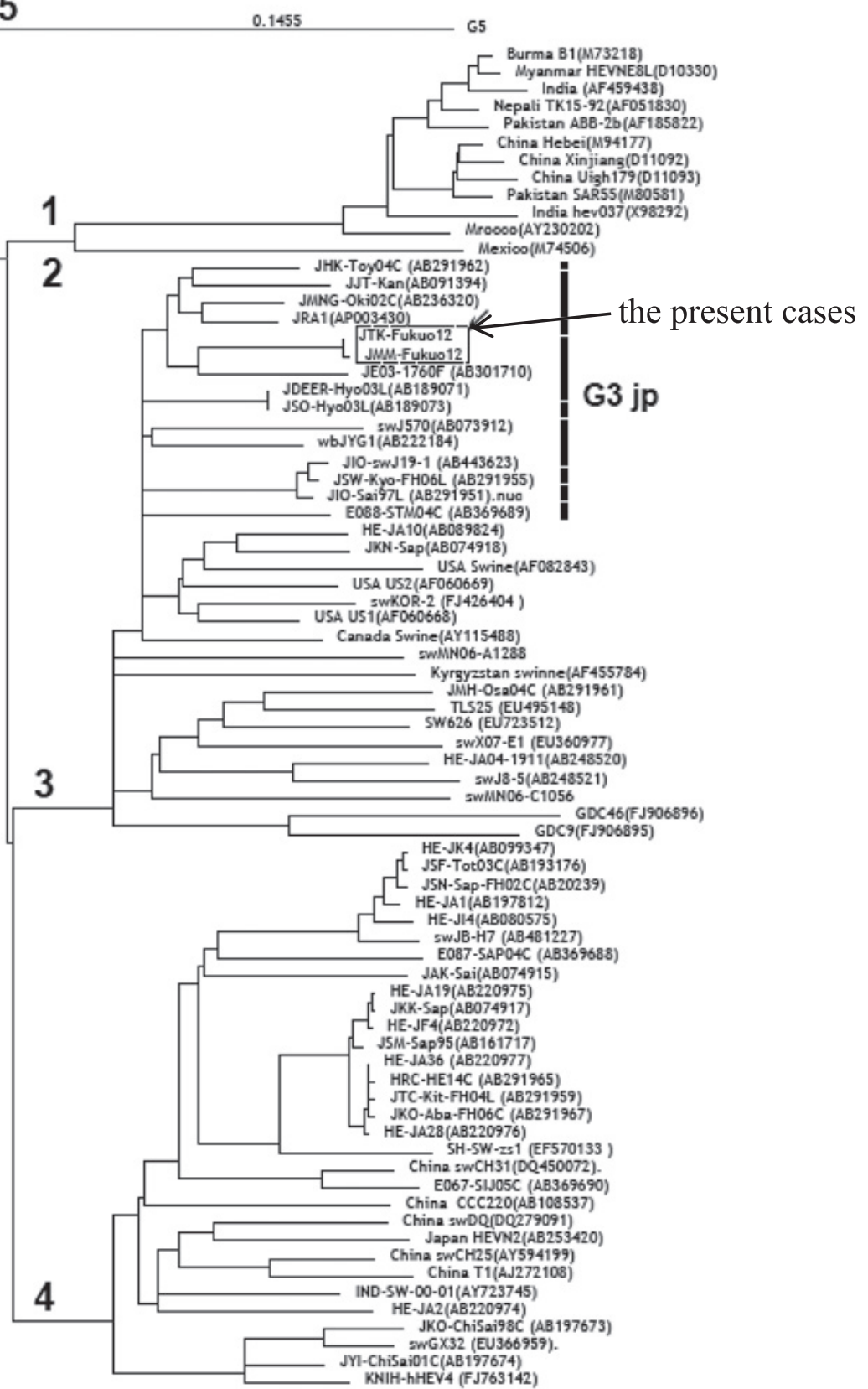

Fig. 2 Phylogenetic tree constructed by the neighbour-joining method based on the partial nucleotide sequence of ORF1 region (326 nt). HEV strains (JTK-Fukuo12, JMM-Fukuo12) which were isolated from the present cases belonged to genotype 3 and segregated into a cluster consisting of human HEV isolates that are presumed to be indigenous to Japan. 
考察 : 今回我々は, 北九州市若松区で同時期に発症 した, $\mathrm{E}$ 型急性肝炎の 2 例から HEV を分離し, ORF1 領域の遺伝子配列解析から 2 種類の 326 塩基長の配列 AB781079 (JTK-Fukuo12), AB781080 (JMM-Fukuo 12)を得た. 興味深いことに, 2 種はいずれも genotype 3 に属し (Fig. 2)，326 塩基長の配列の中で 1 力所が異 なるのみで, $99.7 \%$ の一致率を示した. 比較的狭い地域 内での感染であり, HEV の遺伝子配列に近似性が認め られ, 本地域に土着する HEV 株による感染であると考 えられた。

$\mathrm{E}$ 型肝炎は人獣共通感染症であり, 動物の生肉や内臟 等の摂取歴や流行地域への渡航歴がある場合には診断 は比較的容易と考えられるが, 国内感染例の半数以上 は感染経路が不明とされる ${ }^{2}$. 今回の 2 例は, 詳細な病 歴聴取にもかかわらず，感染経路の特定には至らず， 抗体検查により診断を確定し得た教訓的症例と思われ る.また HEV の遺伝子型により経過が異なることが知 られている3). Genotype 3 では 4 に比べ顕性化率や重症 化率が低く ${ }^{2)}$, 今回の 2 例とも保存的加療のみで肝炎は 軽快した. 本邦の成人の約 $5 \%$ が $\mathrm{HEV}$ 抗体陽性との報 告があり ${ }^{4)}$, 本地域土着の HEV が genotype 3 であると 考えると, 他にも不顕性感染例や, 原因が不明の軽度 の肝炎として処理されている症例が存在する可能性が 考えられた.

今回の検討から, 北部九州に土着する HEV 株の実態 の一部が明らかとなった. $\mathrm{E}$ 型肝炎には重症化例や劇症 化例も存在し, 臟器移植後などでは慢性化することが 報告されている ${ }^{5}$. 報告例の比較的少ない九州地方にお いて, HEV 感染を疑う明らかな病歴がなくても, 原因 不明の急性肝炎を認めた場合には，常に本症を念頭に 置くことが重要であると考えられた.

索引用語： $\mathrm{E}$ 型急性肝炎, 国内感染, 北九州

文献 : 1） Takahashi K, Iwata K, Wanatabe N, et al. Virology 2001; 287:9-12 2 2) 阿部敏紀, 相川達 也，赤羽賢浩，他．肝臓 2006；47：384-391 3）矢野公士, 玉田陽子, 八橋 弘. 日消誌 2009 ; 106 : 188-194 4) Takahashi M, Tamura K,
Hoshino Y, et al. J Med Virol 2010; 82: 271—281

5) Kamar N, Selves J, Mansuy JM, et al. N Engl J

Med 2008; 358: 811-817

本論文内容に関連する著者の利益相反：なし

\section{英文要旨}

Two cases of acute hepatitis due to hepatitis E virus that are indigenous to Kitakyushu: a case report

Yuichi Honma ${ }^{13) *}$, Akinari Tabaru ${ }^{12}$, Eisaku Kita ${ }^{1)}$, Hidehiko Matsuoka ${ }^{1)}$, Kazutaka Shukuwa ${ }^{1)}$, Kazuaki Takahashi' ${ }^{2)}$, Masahiro Arai ${ }^{2}$, Masaru Harada ${ }^{3)}$

Two male patients with liver dysfunction were admitted to our hospital and diagnosed to acute hepatitis $\mathrm{E}$ by detection of IgA class anti-Hepatitis E virus antibody and Hepatitis E virus (HEV) RNA. Following admission, liver dyfunction was improved by conservative treatment. Although the infection route of $\mathrm{HEV}$ was unknown, analysis of HEV genome sequence revealed that the HEV isolated from the two cases belonged to genotype 3 and had homology. So we considered that the HEV strains were presumed to be indigenous to Kitakyushu. Because fulminant hepatitis due to HEV has been reported, even in nonepidemic area, we need to pay attention to acute hepatitis $E$ in treatment of patients with liver dysfunction of unknown origin.

Key words: acute hepatitis E, Kitakyushu, domestic infection

Kanzo 2013; 54: 399-401

1) Department of Gastroenterology and Hepatology, Sangyoikadaigaku Wakamatsu Hospital, Kitakyushu, Japan

2) Department of Medical Sciences, Toshiba General Hospital, Tokyo, Japan

3) Third Department of Internal Medicine, University of Occupational and Environmental Health, School of Medicine, Kitakyushu, Japan

*Corresponding author: y-homma@med.uoeh-u.ac.jp 